\section{Adaptation strategies by paddy-growing farmers to mitigate the climate crisis in Hyderabad-Karnataka region of Karnataka state, India}

\author{
Shanabhoga M.B.
}

Department of Agricultural Extension, National Institute of Veterinary Epidemiology and Disease Informatics, Bangalore, India, and

Krishnamurthy Bommaiah, Suresha S.V. and Shivani Dechamma Department of Agricultural Extension, University of Agricultural Sciences, Bangalore, India
Paddygrowing farmers

Received 28 January 2020 Revised 22 June 2020 14 August 2020 Accepted 15 August 2020

\begin{abstract}
Purpose - The purpose of this paper is to consider the climatic variables and evaluate the role of nonclimatic factors that delicately influence agriculture. This study has come across various adaptation strategies such as modification in cultivation practices such as shifting planting dates, water-saving techniques and strategic nutrient management. Meanwhile, we are trying to forget the ground reality that a majority of the farmers are not aware of climate-resilient production technologies. However, farmers modify themselves in this climate change scenario for sustainable production. The practise of these adaptation strategies helps to reduce vulnerability to improve their "socio-economic status" and the "quality of life".
\end{abstract}

Design/methodology/approach - The present study was attempted to document all the indigenous practices, which are practised by paddy-growers over time for confronting the climate crisis in the Hyderabad-Karnataka region of Karnataka state, India. A cross-sectional and questionnaire-based survey was conducted to collect primary data. The pre-tested interviewing questionnaire consisted of 7 sections with 51 questions. A total of 90 paddy-growing farmers of the region was selected as respondents for the survey. The descriptive statistics was used to analyse the collected data.

Findings - In respect of adopted strategies, the vast majority (96.67\%) of the farmers had used crops as livestock fodder as they fall back in case of failure, followed by the majority $(72.22 \%)$ of the selected appropriate varieties. Cent per cent of the farmers adopted the construction of waterways along the slope for safe disposal of rainwater. An overwhelming portion of the farmers adopted levelling of the land in between the bunds $(96.67 \%)$ and construction of bunds to conserve moisture $(95.56 \%)$. The majority $(76.67 \%)$ of the farmers intensified agricultural activities on irrigated land. Nearly half of them (47.78\%) paddy growers were practising zero tillage to save time and money.

(C) Shanabhoga M.B., Krishnamurthy Bommaiah, Suresha S.V. and Shivani Dechamma. Published by Emerald Publishing Limited. This article is published under the Creative Commons Attribution (CC BY 4.0) licence. Anyone may reproduce, distribute, translate and create derivative works of this article (for both commercial and non-commercial purposes), subject to full attribution to the original publication and authors. The full terms of this licence may be seen at http://creativecommons.org/licences/by/4.0/legalcode

The author would like to thank the faculty of the Department of Agricultural Extension, GKVK, UAS, Bangalore for the persistent support throughout his research work. He would also like to thank the farmers of the Hyderabad-Karnataka region for their co-operation during his interaction.

This paper forms part of special section "Climate change impacts and adaptations in arid and semi-arid regions", guest edited by Zhihua Zhang, Qiang Zhang and Muhammad Jawed Iqbal.

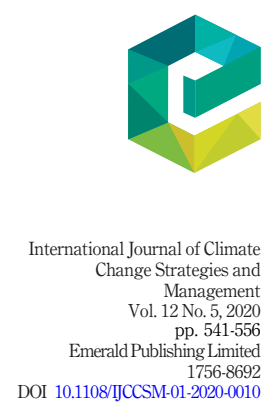


IJCCSM 12,5

Research limitations/implications - The current study was carried out in a few districts of Karnataka. Hence, any policy framed based on the outcomes of this study may not conform to the policy specification needs in general to other parts of the country. The farmers did not maintain record books for updating various records. Therefore, the accuracy of data depends on the memory of the respondents. However, the researcher had made every possible effort to make sure that the data collected are the best of the knowledge of the respondents and bear minimal distortions.

Practical implications - The major constraints to applying agricultural adaptation strategies in the study area have been a general lack of knowledge, expertise and data on climate change issues; a lack of specific climate change institutions to take on climate change work and the need for a better institutional framework in which to implement adaptation. Actions to address these gaps include, namely, training programmes for local government officials, dedicated research activities and post-graduate courses and the initiation of specific institutional frameworks for climate change. Furthermore, improving and strengthening human capital, through education, outreach and extension services, improves decision-making capacity at every level and increases the collective capacity to adapt.

Social implications - Hyderabad-Karnataka is already under pressure from climate stresses, which increases vulnerability to further climate change and reduces adaptive capacity. The adverse effects of climate change have a devastating effect particularly on paddy cultivation, which is the mainstay of most Hyderabad-Karnataka Region. This has affected food production with its resultant effect on widespread poverty. Farmers in the study area have developed traditional agricultural adaptation strategies to cope with climate variability and extreme events. Experience with these strategies needs to be shared among communities.

Originality/value - Though the many literatures were available on the adaptation strategies for climate change this research is one of the few studies to document the farmer led adaptation strategies. This study provides a better understanding of the importance of farmer led adaptation strategies which in turn helps to develop or modify the existing adaptation technologies to cope up with climate change. The authors have come across various adaptation strategies such as modification in cultivation practices such as shifting planting dates, water-saving techniques and strategic nutrient management. Meanwhile, we are trying to forget the ground reality that the majority of the farmers are not aware of climate-resilient production technologies. However, farmers modify themselves in this climate change scenario for sustainable production. The practise of these adaptation strategies helps to reduce vulnerability to improve their "socio-economic status" and the "quality of life". Therefore, farmer-led adaptation strategies to confront with a change in climate require to be recorded.

Keywords Climate change, Vulnerability, Adaptation strategies, Agriculture practices, Climate crisis, Paddy cultivation

Paper type Research paper

\section{Introduction}

Climate is changing rapidly, affecting many areas throughout the globe and it is emerging as a major threat to sustainable development. Globally, an unparalleled increase in greenhouse emissions promotes climate change impacts. Thus, the consequences of climate change affect the food security and agriculture livelihoods of large sections of the urban and rural populations globally. According to the Intergovernmental Panel on Climate Change (IPCC, 2007), South Asia is having the highest proportion of "highly vulnerable" sectors in the Asia sub-regions. Assorted studies have validated the lack of adaptation and mitigation strategies. Climate change will have a baleful effect on agricultural production and economics (Smit and Wandel, 2006). Ray et al. (2013) perceived that with a decline in wheat yield, many areas in India and having a growth rate of $1.1 \%$ per year on a national basis, it is burdensome to take production doubled by 2050. In recent years temperature inconsistency caused substantial yield decline (Rao et al., 2014) as high temperatures can shrink the production of principal food crops radically (Prasad et al., 2000; Teixeira et al., 2013). 
The potential impact of climate change on rice productivity is reported in many recent studies such as Babel et al. (2011), Luo et al. (2013); Soora et al. (2013). Although climatic variables are uncontrollable, factors such as cultivars, soil, water and nutrients can be managed to counteract the adverse effects of climate change (Moradi et al., 2013). Estimating the impact of climate change on crop yield and the evaluation of appropriate adaptation and mitigation strategies are of extreme concern (Jalota et al., 2012; Dharmarathna et al., 2014) to either stabilize or improve the crop yields. Several studies at various places have confirmed that rice cultivation without considering proper adaptation and mitigation strategies is problematic (Adejuwon, 2006; Wassmann et al., 2009; Iizumi et al., 2011; Tao et al., 2012; Poudel and Kotani, 2013). Recent literature has also reported the adequateness of proper agronomic adaptation strategies in relation to climate-induced yield losses in different regions (Tingem and Rivington, 2009; Chhetri and Easterling, 2010; Gouache et al., 2012; Mishra et al., 2013).

Climate change in India may pose additional stresses on ecological and socioeconomic systems that already face tremendous pressures from rapid urbanization, industrialization and economic development. India is the fifth most vulnerable of 181 countries to the effects of climate change, with its poorest being the most at risk (Eckstein et al., 2019). India is among the most affected countries in terms of climate change and natural hazards due to its inadequate arable land, higher population and dependence on agriculture, monsoon dependent farming, limited technological and financial development for adaptation to climate change (Birthal et al., 2014). In particular, crop productivity is likely to experience significant yield loss in the coming days due to climate variability and extreme weather events for instance droughts and floods (Gupta et al., 2014).

Karnataka is the second largest state of India and it is characterized by severe climatic effects such as droughts and floods in the recent past. However, due to the presence of major irrigation projects allowed the farmers to cultivate the different food crops especially paddy. The total area under rice in Karnataka is $1.29 \mathrm{~m}$ ha with an annual production of $3.6 \mathrm{~m}$ and the productivity is $2,630 \mathrm{~kg} / \mathrm{ha}$ during 2014-2015. The major irrigation project Tungabhadra area is referred to as the "Rice Bowl of Karnataka", as nearly $65.00 \%$ of the total (3.63 lakh ha) area of paddy in Karnataka including the Tungabhadra Project (TBP) command area (Ballari, Koppal and Raichur districts). The Tungabhadra river sub-basin, the main area lies within the Krishna River Basin and largely within Karnataka.

Adaptation strategies are operationally defined as the adjustments or remoulding of techniques or practices which are adopted by farmers in their farming such as alteration in crop production, soil and water management, flood management, land use, labour use, livestock management, financial management, family management to cope with the losses or to take benefit of changes in climate. To distinguish the most appropriate adaptation measures, it is an absolute necessity to consider the climatic variables and evaluate the role of non-climatic factors that exquisitely influence agriculture. The ample of the literature of reviews advocated the adaptation strategies like modification in cultivation practices such as shifting planting dates, water-saving techniques and judicious nutrient management. Meanwhile, we have failed to think of the ground reality that most of the farmers are unfamiliar with climate-resilient production technologies. However, farmers modify themselves in this climate change scenario for sustainable production. The adoption of these modifications in practices helps to reduce vulnerability to improve their "socio-economic status" and "well-being". Therefore, farmer-led adaptation strategies to confront climate change needs to be recorded. The first step is to document all the indigenous practices which are practised by Rainfed area farmers over time for confronting climate change. The second step is to quantify the capability of the existing best practices for 
IJCCSM

12,5

\section{4}

climate-induced crises for different crop and livestock production systems. The third step is to develop a long-term strategic research plan to evolve new techniques and practices, which comprises crop varieties and cultivation practices. Hence, the present study was attempted to document all the indigenous practices which are practised by paddy growers over time for confronting the climate crisis in the HyderabadKarnataka region through a primary survey.

\section{Methodology}

\subsection{Study region}

Hyderabad-Karnataka region of Karnataka state, India covers the realm of 44,145 sq.km. Which accounts for $23.02 \%$ of the entire geographical region of the Karnataka state. The region covers six major districts of Karnataka state, namely, Ballary, Koppala, Raichur, Kalburgi, Yadgir and Bidar. This region is characterized by dryness for the major a part of the year and a very hot summer. The region receives rainfall both from southwest and northeast monsoon. However, the mean rainfall within the region is extremely scant at $692 \mathrm{~mm}$ in an exceedingly year. The geographical location of the study area is presented in Figure 1.

\subsection{Study design}

The present research was a cross-sectional and questionnaire-based survey was used for the study. A descriptive and diagnostic research design was used. This research design was used for finding facts with adequate explanations. It clearly states the attributes of given circumstances or groups or individuals (Ray and Mandal, 2006). In this study, the differential level of adoption of adaptation strategies was subjected by using diagnostic research design.

\subsection{Sampling procedure and data}

The cropping pattern of this region varies from district to district. Kharif and Rabi's crops are the 2 seasons during which crops are grown. Summer cultivation is completed only within the small area with assured irrigation. The paddy is cultivated predominantly within

Figure 1.

Map showing the study area

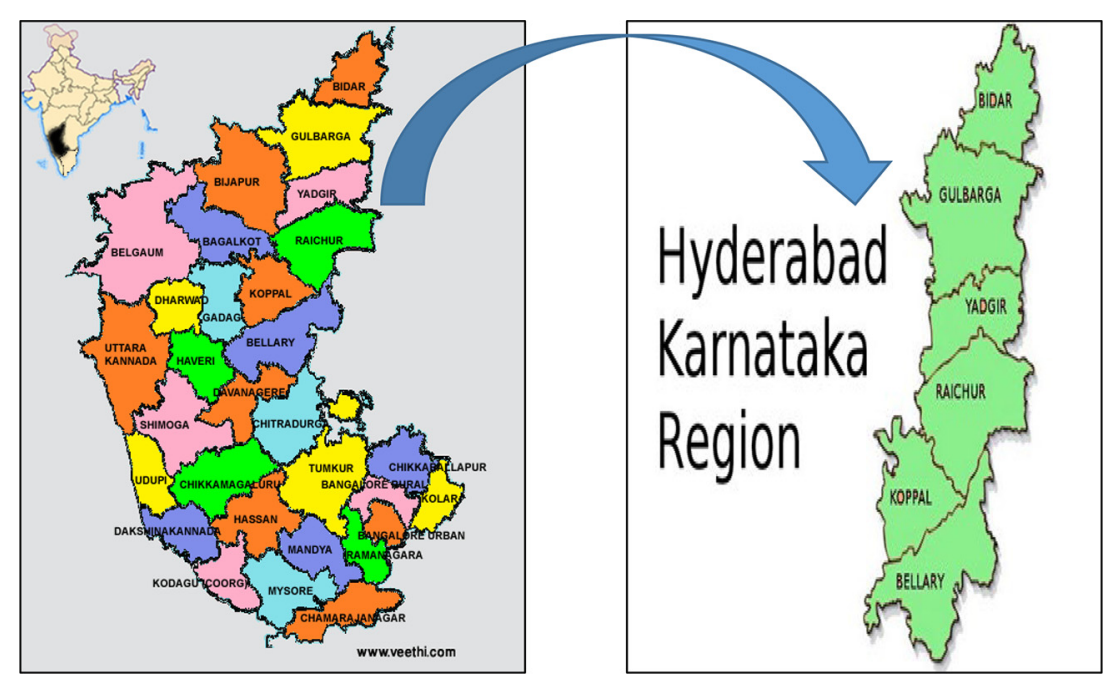


the region with $14.07 \%$ within the command area of the Tungabhadra project which includes Ballary, Koppal and parts of Raichur districts. Based on the area and productivity of the paddy, Ballari, Koppal and Raichur districts were selected for the sampling process. The area under paddy in the Ballari district was found to be 87,007 ha with a productivity of $4,156 \mathrm{~kg} / \mathrm{ha}$, whereas Koppal had an area of 42,611 ha with the productivity of $5,837 \mathrm{~kg} / \mathrm{ha}$ and Raichur had an area of 102,246 ha with the productivity of $3,608 \mathrm{~kg} / \mathrm{ha}$. Taluk representing the highest paddy cropped area in the selected district were selected for the study. In Ballari district Shiraguppa taluk, Sindanur taluk of Raichur district and Gangavathi taluk from Koppal district representing the highest area under paddy was selected. The geographical location of selected taluks and sampling procedures adopted for the primary survey is presented in Figure 2 and Table 1, respectively. Paddy is the
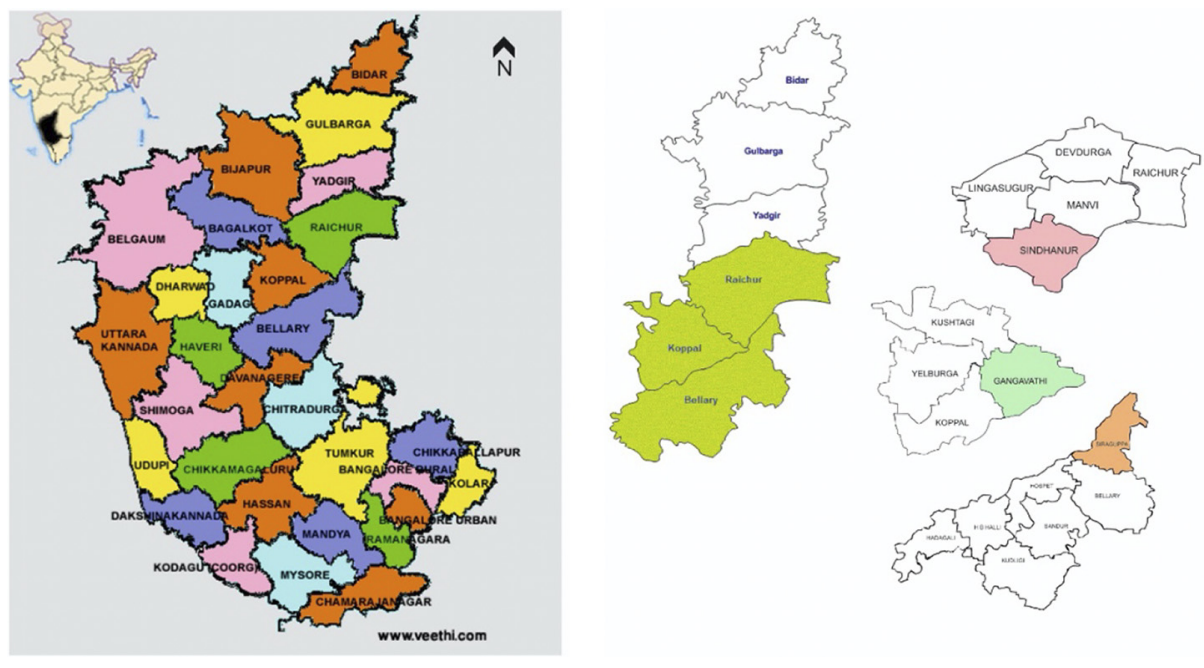

\begin{tabular}{|c|c|c|c|}
\hline Stages & Selection & Unit name/number & Criteria/procedure \\
\hline First stage & $\begin{array}{l}\text { Three high paddy production } \\
\text { districts were selected (out of } \\
\text { six districts of Hyderabad- } \\
\text { Karnataka region) }\end{array}$ & $\begin{array}{l}\text { Ballary, Koppala and } \\
\text { Raichur }\end{array}$ & $\begin{array}{l}\text { Districts were selected based } \\
\text { on the highest number of } \\
\text { paddy production }\end{array}$ \\
\hline Second stage & $\begin{array}{l}\text { One taluk* from each district } \\
\text { was selected }\end{array}$ & $\begin{array}{l}\text { Shirguppa from Ballary } \\
\text { district } \\
\text { Gangavati from Koppala } \\
\text { district } \\
\text { Sindanur from Raichur } \\
\text { district }\end{array}$ & $\begin{array}{l}\text { The taluks were selected based } \\
\text { on the highest paddy } \\
\text { production }\end{array}$ \\
\hline Third Stage & $\begin{array}{l}\text { Major paddy-growing } \\
\text { farmers }\end{array}$ & $\begin{array}{l}30 \text { farmers were selected } \\
\text { from each taluk } \\
\text { comprising of } 90 \text { farmers }\end{array}$ & $\begin{array}{l}\text { A general rule of thumb for the } \\
\text { large enough sample condition } \\
\text { is that } n \geq 30 \text {, where } n \text { is your } \\
\text { sample size. Cohen (1990). }\end{array}$ \\
\hline
\end{tabular}

Note: *Taluks are administrative sub-units of the district and it may vary from 2 to 10 or more depending on the geographical area of the district

Table 1.

Sampling procedure adopted for the primary survey in the HyderabadKarnataka region 
IJCCSM 12,5

predominantly cultivated crop in the study region and Farmers are the most vulnerable group of the community, and they are directly affected by the climatic change. Hence, a total of 90 paddy-growing farmers were surveyed in the study region from 2018 to 2019.

\subsection{Survey method}

The interview schedule was prepared after reviewing related literature. Before conducting the survey in the field, a pilot study was carried out with 30 randomly selected farmers who were growing paddy to test the clarity, reliability and validity of the interview schedule. Following this study, the interview schedule was revised and finalized in accordance with suggestions and data were collected among the study population. The final interview schedule consisting of 7 sections and 51 questions. The first part included adaptation related to crop production includes 17 questions, the second part is related to soil and water conservation practices include 10 questions, the third party related to livestock management includes seven questions, the fourth question related to land use consists four questions, Section 5 related to labour use consists four questions, sixth part related to financial management includes five questions and final part related to family management includes four questions. All the part questions were framed in a closed-end format.

In the spirit of Mann (1917) village studies, Resident Investigator Concept was adopted for gathering data from the respondents. Many of the early studies in the agricultural extension concerning farmers followed a common format of interviews by visits. However, it was felt that these snapshot approaches do not help an in-depth understanding of the situation. Also, under this approach, research relies mainly on data gathered through structured interviews but fails to recognize the importance of informal discussion and observations made in the village. Therefore, in view of this and also keeping the importance of the study, an ethnographic approach of anthropologists was adopted.

Accordingly, the researcher resided in the village for 10 to 15 days for data collection. Before the actual data collection, preliminary rapport establishing contacts were made along with the key informants of the village or Agricultural Assistant of the village. Afterwards, using the village family list, each farmer was contacted and interviewed in an informal atmosphere. Each questionnaire was explained clearly before eliciting the response, and the influence of onlookers was also avoided.

In addition to the interview, the researcher's stay in the study villages provided an opportunity for informal discussions and also to make some observations related to the research study. All these helped investigators to interpret the results in the full context of material and non-material relationships existing in the community.

\subsection{Data analysis}

The collected data were scored, quantified, analyzed, categorized and tabulated by using descriptive statistics such as mean, standard deviation, frequencies and percentages. The classification of the farmers based on adoption scores was done on the basis of mean - S.D. (Low), mean \pm S.D. (Medium), Mean + S.D. (High). All the tests were carried out using Microsoft Windows Excel and SPSS Version 22.0.

\section{Result and discussion}

\subsection{Adaptation strategies adopted by paddy growers related to crop production in response to the climate crisis}

The climate crisis has a catastrophic impact on sustainable agriculture. Extreme weather conditions affect the crop development, growth and yield of paddy. The high temperature at critical growth stages could reduce the grain filling duration caused the grains sterility and 
consequently yield reduction. To avoid the risks in agriculture associated with climate change, adaptation is the key factor that could help to mitigate the negative of the climate crisis. Adaptation strategies provide an opportunity to address the climate crisis challenges and to sustain the crop production Fischer et al. (2002).

Table 2 shows that the adaptation strategies practised by the paddy growers. In respect of adopted strategies, the vast majority $(96.67 \%$ ) of the farmers had used crops as livestock fodder as they fall back in case of failure, followed by the majority $(72.22 \%)$ of the selected appropriate varieties. It is needless to explain that both dry and wet paddy straw will be used as a feed to livestock. It is also seen that to get adjusted with climatic variability and also to get better returns from the crop in a short time, farmers prefer short-duration varieties over the long duration varieties. Slightly more than two-thirds $(67.78 \%)$ of the farmers reduced plant population during stress seasons and almost two-thirds (65.56\%) of them prefer to avoid crop cultivation from vulnerable areas. Similarly, almost the same proportion $(63.33 \%)$ of them apply balanced chemical fertilizers for crops. As the stress period in crop production is considered a critical stage, paddy farmers prefer to reduce plant populations to maintain the balance in crop production. Most of the paddy growers avoiding the cultivation of paddy on the river bank, as well as non-irrigated areas due to the uncertainty of water flow and shortage of water, respectively. Though the good numbers of farmers were applying balanced fertilizer to get a higher yield, still a majority of farmers had resorted to the reduction in the fertilizer dose.

Adaptation strategies such as shifting from paddy crops to perennial crops, direct seeding methods, increasing space between the rows or plants and diversifying the cultivation to many crops were not practised by the majority of the paddy growers. In the Hyderabad-Karnataka region canals are the most important source of irrigation. The area irrigated by canals is $56.56 \%$ of the net irrigated area. This is due to the implementation of major irrigation projects such as the Karanja, Upper Krishna Project and Tungabhadra projects in the region (The Government of Karnataka, 2015). Paddy is getting a stable price

\begin{tabular}{|c|c|c|c|c|c|c|}
\hline \multirow[b]{2}{*}{ Sl.no } & \multirow[b]{2}{*}{ Adaptation strategies } & \multicolumn{2}{|c|}{ Adopted } & \multicolumn{2}{|c|}{ Not adopted } & \\
\hline & & No. & $(\%)$ & No. & $(\%)$ & \\
\hline 1 & Selection of appropriate crop/varieties & 65 & 72.22 & 25 & 37.78 & \\
\hline 2 & Increasing seed rate & 39 & 43.33 & 51 & 56.67 & \\
\hline 3 & Changing in planting dates & 48 & 53.33 & 42 & 46.67 & \\
\hline 4 & Increasing the no. of seedling hill & 35 & 38.89 & 55 & 61.11 & \\
\hline 5 & Planting of aged seedlings (one week more than normal age) & 49 & 54.44 & 41 & 45.56 & \\
\hline 6 & Direct seeding method & 19 & 21.11 & 71 & 78.89 & \\
\hline 7 & Increasing space between the rows/plants & 24 & 26.67 & 66 & 73.33 & \\
\hline 8 & Raising community nursery & 48 & 53.33 & 42 & 46.67 & \\
\hline 9 & Avoiding crop cultivation from vulnerable areas & 59 & 65.56 & 31 & 34.44 & \\
\hline 10 & Shifting from paddy crops to perennial crops & 12 & 13.33 & 78 & 86.67 & \\
\hline 11 & Diversifying the cultivation to many crops & 24 & 26.67 & 66 & 73.33 & Table 2. \\
\hline 12 & Using crops as livestock fodder as they fall back in case of failure & 87 & 96.67 & 3 & 3.33 & Adaptation \\
\hline 13 & Applying balanced chemical fertilizer to rainfed crops & 57 & 63.33 & 33 & 36.67 & strateoies adonted by \\
\hline 14 & Practices of SRI method & 31 & 34.44 & 59 & 65.56 & strategies adopted by \\
\hline 15 & Intensified the Rabi crop cultivation during Kharif crop failure. & 44 & 48.89 & 46 & 51.11 & paday grow \\
\hline 16 & Adopting IPM methods for pest management & 46 & 51.11 & 44 & 48.89 & related to $\mathrm{C}$ \\
\hline 17 & Reducing plant population during stress season & 61 & 67.78 & 29 & 32.22 & production \\
\hline \multicolumn{2}{|c|}{ Note: $n=90$} & & & & & climate crisis \\
\hline
\end{tabular}

Note: $n=90$ 
IJCCSM

12,5

\section{8}

over a period of time as it is covered under the minimum support price fixed by the government of India. Hence, the majority of the farmers were growing paddy after paddy, and it is considered as a monocropping zone. Several efforts were made to change the cropping pattern to maintain the soil health in the study area, but efforts were not yielding the desired results. Though the direct seeding method is a profitable and water-saving cultivation method, farmers were practicing the traditional method of cultivation. This is because of a lack of awareness and knowledge about the direct seeding method. These findings are similar to the study conducted by Schlenker and Lobell (2010) and Vinaya Kumar et al. (2017a, 2017b).

\subsection{Adaptation strategies adopted by paddy growers related to soil and water conservation in response to the climate crisis}

More than $75.00 \%$ of the rice produced comes from irrigated land. However, the water crisis threatens the sustainability of the irrigated system. Rice is extremely sensitive to declining water availability, as it requires more water than the opposite food crop and it is relatively low water-use efficiency. Through the adoption of water-saving irrigation technologies, rice land will shift off from being continuously anaerobic to being partly or even completely aerobic. This could have major consequences for other aspects of sustainability, such as weed, pest and disease ecology and nutrient and soil organic matter dynamics

Adaptation strategies related to soil and water conservation among paddy growers are depicted in Table 3 . In total, $100 \%$ of the farmers adopted the construction of waterways along the slope for safe disposal of rainwater. An overwhelming portion of the farmers adopted levelling of the land in between the bunds $(96.67 \%)$ and construction of bunds to conserve moisture $(95.56 \%)$. Exactly two-thirds $(66.67 \%)$ of the farmers adopted the application of farmyard manure. The majority of the paddy growers in the study area practicing the traditional method of paddy cultivation, where water stagnation will be the key point. The land preparation is a principle practice in paddy cultivation where construction of bund and levelling the land were the two major components. This is to stagnation of water and to conserve the moisture in the field. To drain the excess water from the field, they construct the waterways.

The three-fifth $(64.44 \%)$ of the farmers did not adopt gully plugging to avoid soil loss, followed by more than half $(56.67 \%)$ of them did not adopt the stabilization of the bund by planting grasses/sp. Almost half of the paddy growers never constructed of farm pond to

\section{Table 3.}

\section{Adaptation} strategies adopted by paddy growers related to soil and water conservation in response to the climate crisis

\begin{tabular}{|c|c|c|c|c|c|}
\hline Sl.no. & Adaptation strategies & & $\begin{array}{r}\text { lopted } \\
(\%)\end{array}$ & $\begin{array}{l}\text { Not a } \\
\text { No. }\end{array}$ & $\begin{array}{c}\text { dopted } \\
(\%)\end{array}$ \\
\hline 1 & Construction of bunds to conserve moisture & 86 & 95.56 & 4 & 4.44 \\
\hline 2 & Stabilization of the bund by planting grasses/sp & 39 & 43.33 & 51 & 56.67 \\
\hline 3 & Construction of waterways along with the safe slope disposal of rainwater & 90 & 100.00 & 0 & 0.00 \\
\hline 4 & Gully plugging to avoid soil loss & 32 & 35.56 & 58 & 64.44 \\
\hline 5 & Alternative dry and wetting method & 44 & 48.89 & 46 & 51.11 \\
\hline 6 & Levelling of the land in between the bunds & 87 & 96.67 & 3 & 3.33 \\
\hline 7 & Construction of farm pond to store rainwater & 43 & 47.78 & 47 & 52.22 \\
\hline 8 & Application of farmyard manure & 60 & 66.67 & 30 & 33.33 \\
\hline 9 & Adoption of water-saving cultivation methods & 54 & 60.00 & 36 & 40.00 \\
\hline 10 & Protective irrigation during critical stages & 73 & 81.11 & 17 & 18.89 \\
\hline
\end{tabular}


store rainwater $(52.22 \%)$ and did not adopt alternative dry and wetting method $(51.11 \%)$. The majority of the paddy fields were well prepared for the cultivation of paddy, and similarly, bunds in paddy fields were small and they are not big enough to cultivate the grass. The paddy growers were having a good source of irrigation facilities and they never found the necessity of storing water in the pond, but still half of the respondents had ponds due to government intervention schemes. These findings are familiar with the results of the study conducted by Muthanna (2013) and Vinaya Kumar and Shivamurthy (2018).

\section{Paddy- growing farmers}

\subsection{Adaptation strategies adopted by paddy growers related to livestock management in response to the climate crisis}

It is important to understand the management of livestock in a rural area as it provides assured and sustainable income by milk, meat and wool production. In addition to that, the livestock is responsible for maintaining the nutritional security of the household. Hence, dairy is considered as a secondary occupation in rural areas due to the ill effects of climate change on agricultural production in a recent period. Table 4 shows the adaptation strategies related to livestock management among paddy growers. The majority $(86.67 \%)$ of the farmers adopted the preservation of fodder followed by an almost similar proportion of the farmers who adopted supplementary feed to livestock (64.44\%) and owning of multispecific holding of livestock (63.33\%). Paddy crop is considered as one of the main sources of fodder for livestock, which influence them to preserve fodder for the dry season and silage making. The women of the farmers' household will look after the animals and they prefer to rear a few sheep and goat for household consumption purposes.

Among the non-adopted strategies, two-third $(68.89 \%)$ of the farmers did not prefer to increase the number of small animals (sheep and goat) and decreased the number of big animals (buffalos and cows). The majority of the farmers are already rearing big animals such as cows and buffalos and they do not want to take much burden by increasing the small animals. Less than two-thirds (62.22\%) of them did not adopt rearing of sheep/goat to meet emergency financial needs followed by more than half $(57.78 \%)$ of them did not grow fodder crops in a small portion of irrigated area. The farmers were not ready to waste their irrigated land by growing fodder crops as they were already using paddy as fodder for their animals. These results are in accordance with a research study conducted by Muthanna (2013) and Vinaya Kumar and Shivamurthy (2018).

\begin{tabular}{llcccc}
\hline & & \multicolumn{3}{c}{ Adopted } & \multicolumn{2}{c}{ Not adopted } \\
Sl.no. & Adaptation strategies & No. & $(\%)$ & No. & $(\%)$ \\
\hline 1. & Supplementary feed to livestock & 58 & 64.44 & 32 & 35.56 \\
2. & An increasing number of small animals (sheep and goat) and & 28 & 31.11 & 62 & 68.89 \\
& $\quad$ decreased the number of big animals (buffalos and cows) & & & & \\
3. & Start rearing sheep/goats to meet emergency financial need & 34 & 37.78 & 56 & 62.22 \\
4. & Owning of multi specific holding of livestock (cows + buffalo & 57 & 63.33 & 33 & 36.67 \\
& + goats + sheep) & 40 & 44.44 & 50 & 55.56 \\
5. & Planting improved grass slips & 38 & 42.22 & 52 & 57.78 \\
6. & Grown fodder crop in a small portion of irrigated area & 78 & 86.67 & 12 & 13.33 \\
7. & Preservation of fodder & & & &
\end{tabular}

Note: $n=90$

Table 4. Adaptation strategies adopted by paddy growers related to livestock management in response to the climate crisis 
IJCCSM

12,5

\section{0}

\subsection{Adaptation strategies adopted by paddy growers related to land use in response to the climate crisis}

Adaptation strategies concerning land use among paddy growers are presented in Table 5. The three-fourth $(76.67 \%)$ of the farmers intensified the agricultural activities on irrigated land. Nearly half of them $(47.78 \%)$ were practicing zero tillage to save time and money. As the paddy cultivation is taken in the Tungabhadra command area and the farmers had adequate irrigation facilities. Hence, farmers have taken up two to three crops of paddy in the same land for the entire year. It is visibly evident that paddy growers are practicing a mono-cropping system having said that due to a shortage of time between one crop to another crop farmers prefer to carry out zero tillage to save their time and money.

Less than two-thirds ( $65.56 \%$ ) of the paddy growers did not prefer to bring more dry land under cultivation to increase total yield even when rainfall is scarce and they do not want to convert paddy field for a different purpose (63.33\%). The majority of the farmers were not ready to bring more dry land under cultivation; this is because farmers are not prepared to take up any risk by taking additional responsibility for cultivation. The probable reason for not converting the paddy field into different purposes is a difficult task and they do not want to lose their cultivable land. The results are in accordance with the outcome of the study conducted by Vinaya Kumar et al. (2017a) and Vinaya Kumar and Shivamurthy, 2018).

\subsection{Adaptation strategies adopted by paddy growers related to labour used in response to the climate crisis}

Labour is one of the key inputs in the agricultural production system. How it is measured and valued is critical for establishing the cost of producing agricultural commodities and accurately portraying labour's relative share of the total cost of production. The effective management of labours in the farm during the climate crisis will save an extra penny for farmers to withstand the climatic shocks. Adaptation strategies for labour use among paddy growers reported in Table 6 . It shows that two-third $(67.78 \%)$ of the farmers adopted diversification of labour use from crop to livestock followed by $62.22 \%$ of them adopted labour-saving implements for cultivation. More than half (58.89\%) of the respondents adopted reducing the number of waged labours used on the farm. The majority of the paddy growers had a fair amount of livestock possession, which requires labour force for better management and also cut off the labour cost. On the other hand non-availability of the labours force the farmers to adopt labour-saving machinery.

Slightly more than half $(53.33 \%)$ of the respondents did not prefer to increase the number of family labourers to avoid waged labourers, followed by a reduction of the number of labourers used on a farm. The fair number of farmers were ready to reduce the number of

\begin{tabular}{|c|c|c|c|c|c|c|}
\hline \multirow{8}{*}{$\begin{array}{l}\text { Table } 5 . \\
\text { Adaptation } \\
\text { strategies adopted by } \\
\text { paddy growers } \\
\text { related to land use in } \\
\text { response to the } \\
\text { climate crisis }\end{array}$} & \multirow[b]{3}{*}{ Sl.no. } & \multirow[b]{3}{*}{ Adaptation strategies } & \multicolumn{4}{|c|}{ Adaptation strategies } \\
\hline & & & \multicolumn{2}{|c|}{ Adapted } & \multicolumn{2}{|c|}{ Not adopted } \\
\hline & & & No. & $(\%)$ & No. & $(\%)$ \\
\hline & 1 & $\begin{array}{l}\text { Brining more dry land under cultivation to increase total yield } \\
\text { even when rainfall is scarce }\end{array}$ & 31 & 34.44 & 59 & 65.56 \\
\hline & 2 & Intensified the agricultural activities on irrigated land & 69 & 76.67 & 21 & 23.33 \\
\hline & 3 & Conversion of paddy field to a different purpose & 33 & 36.67 & 57 & 63.33 \\
\hline & 4 & Zero tillage to save time and money & 43 & 47.78 & 47 & 52.22 \\
\hline & \multicolumn{6}{|c|}{ Note: $n=90$} \\
\hline
\end{tabular}


labourers in farming activities because of the high wage rate, as well as the availability of machinery, along with these farmers were ready to involve family members as labourers to carry out agricultural activities both at the farm and household level. The results are in agreement with the conclusions of a study conducted by Vinaya Kumar et al. (2017a) and Vinaya Kumar and Shivamurthy, 2018).

3.6 Adaptation strategies adopted by paddy growers related to financial management in response to the climate crisis

A rupee saved is a rupee earned. Having said that financial management on the farm is a critical factor, which is neglected by farmers due to various socio-economic factors. An idiot with a plan can beat a genius without a plan. Hence, a sound financial plan will help the farmer to withstand the losses induced by the climate crisis.

Table 7 depicts the adaptation strategies related to financial management among paddy growers. More than two-thirds $(68.89 \%)$ of the respondents had started to save money during the normal years for using during the drought year and two-third (66.67\%) of the farmers borrowed crop loans in credit cooperative societies/primary land development bank. Less than half $(48.89 \%)$ of the respondents borrowed a loan from a commercial bank. The presence of local co-operative societies and primary land development (PLD) banks had a greater influence on the financial status of the farmers. Hence, the majority of the farmers prefer to borrow loans from co-operative societies and PLD banks because of its low-interest rates. The paddy growers had a better saving habit and having said that, they prefer to save money during normal years so it could be useful for them during drought years.

\begin{tabular}{llcccr}
\hline & & \multicolumn{3}{c}{ Adopted } & \multicolumn{2}{c}{ Notadopted } \\
Sl.no. & Adaptation strategies & No. & (\%) & No. & $(\%)$ \\
\hline 1 & Reducing the number of waged labourers used on a farm & 53 & 58.89 & 37 & 41.11 \\
2 & Increase the number of family labourers to avoid waged & 42 & 46.67 & 48 & 53.33 \\
& labourers & & & & \\
3 & Use of labour-saving implements for cultivation & 62.22 & 34 & 37.78 \\
4 & Diversification of labour use from crop to livestock & 61 & 67.78 & 29 & 32.22
\end{tabular}

Note: $n=90$

Adaptation strategies

Adopted Not adopted

Sl.no. Adaptation strategies

No. $(\%) \quad$ No. $(\%)$

1 Borrowing loan from commercial bank

2 Borrowing crop loan in credit cooperative societies/ PLD Bank

3 Insuring crops of rainfed and irrigated land

$4 \quad$ Starting to save money during the normal year for using during a drought year

$5 \quad$ Keeping account on expenditure and returns

$\begin{array}{llll}44 & 48.89 & 46 & 51.11\end{array}$

$\begin{array}{llll}60 & 66.67 & 30 & 33.33\end{array}$

$\begin{array}{llll}35 & 38.89 & 55 & 61.11\end{array}$

$\begin{array}{llll}62 & 68.89 & 28 & 31.11\end{array}$

$\begin{array}{llll}35 & 38.89 & 55 & 61.11\end{array}$
Paddygrowing farmers
Table 6.

Adaptation strategies adopted by paddy growers related to labour used in response to the climate crisis

Note: $n=90$

Table 7. Adaptation strategies adopted by paddy growers related to financial management in response to the climate crisis 
IJCCSM

12,5

\section{2}

The same portion $(61.11 \%)$ of the respondents did not adopt crop insurance of rainfed and irrigated land and keeping accounts on expenditure and returns. The lack of awareness and information about the crop insurance will lead the farmer for non- adoption of insuring the crops. The majority of the farmers expressed that they did not understand the procedure for crop insurance, as well as claiming processes and some of them also revealed that it is a complex process. Though the farmers want to keep an account on their expenditure and returns because of lack of time and untimely expenditures, hamper their saving ability. The results are in conformity with the outcomes of the study conducted by Vinaya Kumar et al. (2017a) and Vinaya Kumar and Shivamurthy (2018).

\subsection{Adaptation strategies adopted by paddy growers related to family management in response to the climate crisis}

Adaptation strategies related to family management among paddy growers are shown in Table 8. Slightly more than two-thirds $(67.78 \%)$ of the respondents reduced spending on costly food items. More than half $(56.67 \%)$ of the respondents had adopted the selling of jewels during the distress year and reducing the expenditure for social functions and festivals (54.44\%). The majority of farmers prefer homemade food rather than outside food. This is because farmers were aware of healthy food, and they do not want to spend unnecessarily on costly food items. In general, the jewelleries were considered assets; hence, most of the farmers were ready to invest in gold, which can be used in difficult times. A good number of farmers expressed that they are ready to reduce the expenditure on social functions and festivals.

With respect to non-adaptation strategies, two-third $(67.78 \%)$ of them did not adopt borrowing food grains from relatives. Farmers expressed that, in recent days, they have sufficient food availability and accessibility because of various government schemes. Hence, most of the people were not preferred to borrow food items from relatives except some situations like shortage while cooking, during functions. The results are following the conclusion of the study conducted by Vinaya Kumar (2015, 2017c).

\subsection{Overall adaptation strategies adopted by paddy growers in response to the climate crisis}

The farmers were categorized based on the standard deviation and mean score. Overall adaptation strategies adopted among the paddy growers are presented in Table 8 and Figure 3. Nearly half (48.89\%) of the farmers belonged to medium level category followed by less than one third $(27.78 \%$ ) of them belonged to a high-level category. Finally, almost one fourth $(23.33 \%)$ of them belonged to the low-level category. As discussed in the above paragraph, the majority of the paddy growers were not adopting simple practices such as direct seeding methods, raising community nursery and diversified cropping systems. Hence, the farmers belonged to a medium level of adaptation strategies to various aspects of

Table 8.

Adaptation strategies adopted by paddy growers related to family management in response to the climate crisis 
the climate crisis. The study conducted from Shanabhoga et al. (2019), concluded that Raichur (0.775), Koppala (0.567) and Ballary (0.560) districts were having a high degree of adaptive capacity for climate vulnerability among the Hyderabad-Karnataka Region. This could be increased in the coming days by enhancing their level of understanding about the climate crisis and creating awareness about improved cultivation practices, as well as other adaptation strategies (Table 9).

\section{Conclusion}

Hyderabad-Karnataka region is already under coercion from climate stresses, which proliferate vulnerability to further climate crisis and diminish the adaptive capacity. The detrimental effects of climate crisis hamper the paddy cultivation, which is the backbone of most HyderabadKarnataka region. This has influenced the poor food production and thereby effect on pervasion of poverty. Farmers in the study area are blended the traditional agricultural adaptation strategies with new techniques to confront climate variability and extreme events. The success of these potential strategies needs to be dispense among communities. Methods include, namely, diversification of cluster, income and labours, different and improved crop production technologies, improved soil and water management techniques, a delegation of government resources, livestock management techniques and the handling of land use leading to land-use conversion, to name a few. However, these potential techniques and strategies need to validate with scientific evidence from the scientific community for wider adaptation to face additional climate risks accompanying with the climate crisis.

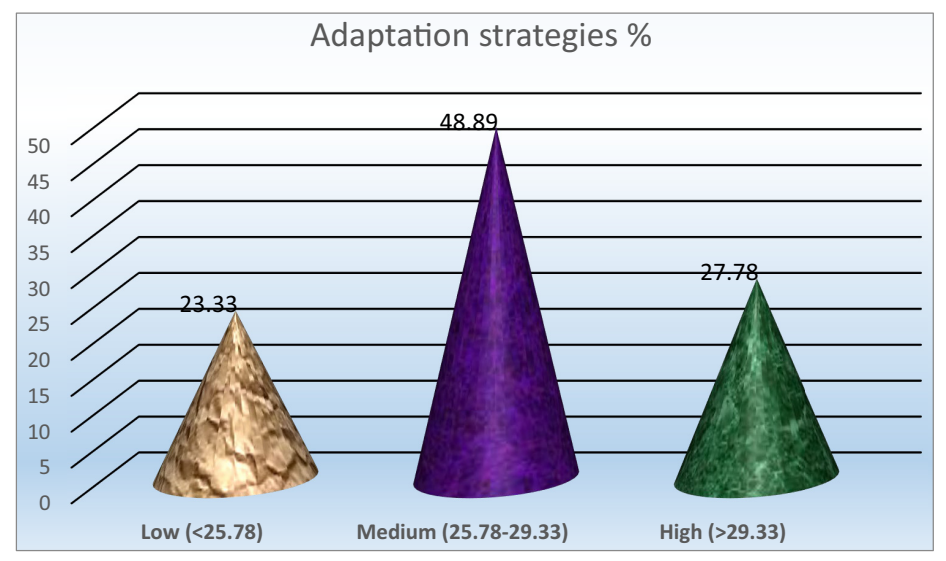

Figure 3.

Overall adaptation strategies adopted by paddy growers in response to the climate crisis

\begin{tabular}{llcr}
\hline & & \multicolumn{2}{c}{ Adaptation strategies } \\
Sl. no. & Category & No. & $(\%)$ \\
\hline 1 & Low $(<25.78)$ & 21 & 23.33 \\
2 & Medium $(25.78-29.33)$ & 44 & 48.89 \\
3 & High $(>29.33)$ & 25 & 27.78
\end{tabular}

Notes: $n=90$; mean: $27.56 ; \mathrm{SD}=3.54$

Table 9.

Overall adaptation strategies adopted by paddy growers 
IJCCSM

12,5

\section{4}

\section{Implications}

- The different farmers in the study region are practicing different approaches in adopting these adaptation strategies. The different approaches are because of their knowledge, expertise and availability of resources and lack of an institutional framework to tackle the climate crisis. The specific interventions such as demonstration of improved technologies, training programmes for local government officials, dedicated research activities and the initiation of specific institutional frameworks for climate crisis to address these gaps.

- Furthermore, education, outreach and extension services can play a key role in strengthening human capital, improves decision-making capacity at every level and increases the collective capacity to adapt. Hence, the extension bodies should be strengthened at the grass-root level.

- The paddy-growing farmers are practicing mono-cropping pattern as the study region is having sufficient irrigation. Hence, the local government and research institutes should popularize and encourage the farmers to adopt an integrated farming system for sustainable income and productivity of the farm.

- In financial management crop insurance plays a key role to withstand the climate changeinduced crisis during the production period. Hence, the government and line departments will take necessary policy actions to reduce the burden of excessive production cost.

- These adaptation strategies could be adopted by the paddy growers in similar setups to mitigate the climate crisis for better productions and thereby sustaining the income.

\section{Ethical approval}

Ethical approval was obtained from the Department of Agricultural Extension, University of Agricultural Sciences, Bangalore. The oral consent of selected farmers was sought and obtained after explaining the purpose of the study.

\section{Reference}

Adejuwon, J.O. (2006), "Food crop production in Nigeria. II. Potential effects of climate change", Climate Research, Vol. 32, pp. 229-245.

Anonymous (2015), "State wise area, production and yield of rice 2014-15. Directorate of economics and statistics, ministry of agriculture", Govt. of India, pp. 151-152.

Babel, M.S., Agarwal, A., Swain, D.K. and Herath, S. (2011), "Evaluation of climate change impacts and adaptation measures for rice cultivation in northeast Thailand", Climate Research, Vol. 46 No. 2 , pp. 137-146.

Birthal, P.S., Khan, T.M., Negi, D.S. and Agarwal, S. (2014), "Impact of climate change on yields of major food crops in India: implications for food security", Agricultural Economics Research Review, Vol. 27 No. 2, pp. 145-155.

Chhetri, N.B. and Easterling, W.E. (2010), "Adapting to climate change: retrospective analysis of climate technology interaction in the rice-based farming system in Nepal", Annals of the Association of American Geographers, Vol. 100 No. 5, pp. 1156-1176.

Cohen, J. (1990), “Things I have learned (so far)”, American Psychologist, Vol. 45 No. 12, pp. 1304-1312.

Dharmarathna, W.R.S.S., Herath, S. and Weerakoon, S.B. (2014), "Changing the planting date as a climate change adaptation strategy for rice production in Kurunegala district, Sri Lanka", Sustainability Science, Vol. 9 No. 1, pp. 103-111. 
Eckstein, D., Künzel, V., Schäfer, L. and Winges, M. (2019), “Global climate risk index 2020: who suffers most from extreme weather events? Weather-related loss events in 2018 and 1999-2018", Germanwatch, Bonn, available at: https://germanwatch.org/sites/germanwatch.org/files/20-201e\%20Global\%20Climate\%20Risk\%20Index\%202020_14.pdf

Fischer, G., Shah, M. and van Velthuizen, H. (2002), Climate Change and Agricultural Vulnerability. A Special Report Prepared as a Contribution to the World Summit on Sustainable Development, International Institute for Applied Systems Analysis, Laxenburg, Austria.

Gouache, D., Bris, X.L., Bogarda, M., Deudone, O., Pagéd, C. and Gatee, P. (2012), "Evaluating agronomic adaptation options to increasing heat stress under climate change during wheat grain filling in France", European Journal of Agronomy, Vol. 39, pp. 62-70.

Gupta, S., Sen, P. and Srinivasan, S. (2014), "Impact of climate change on the Indian economy: evidence from food grain yields", Climate Change Economics, Vol. 05 No. 02, p. 1450001, doi: 10.1142/ S2010007814500018.

Iizumi, T., Yokozawa, M. and Nishimori, M. (2011), "Probabilistic evaluation of climate change impacts on paddy rice productivity in Japan”, Climatic Change, Vol. 107 No. 3-4, pp. 391-415.

IPCC (2007), "Climate change (2007): impacts, adaptation and vulnerability. Contribution of working group II to the fourth assessment report of the intergovernmental panel on climate change", in Parry, M.L., Canziani, O.F., Palutikof, J.P., van der P.J. L. and Hanson, C.E. (Eds), Cambridge University Press, Cambridge, p. 976, doi: 10.2134/jeq2008.0015br.

Jalota, S.K., Kaur, H., Ray, S.S., Tripathi, R., Vashisht, B.B. and Bal, S.K. (2012), "Mitigating future climate change effects by shifting planting dates of crops in rice-wheat cropping system", Regional Environmental Change, Vol. 12 No. 4, pp. 913-922.

Luo, Y., Jiang, Y., Peng, S., Cui, Y., Khan, S., Li, Y. and Wang, W. (2013), "Hindcasting the effects of climate change on rice yields, irrigation requirements, and water productivity", PaddyWat Environ, doi: 10.1007/s10333-013-0409-8.

Mann, H. (1917), Land and Labor in Deccan Village. Economic Series No. 1, University of Bombay. Oxford University Press. London and Bombay.

Mishra, A., Siderius, C., Aberson, K., van der Ploeg, M. and Froebrich, J. (2013), "Short-term rainfall forecasts as a soft adaptation to climate change in irrigation management in North-East India", Agricultural Water Management, Vol. 127, pp. 97-106.

Moradi, R., Koocheki, A., Mahallati, M.N. and Mansoori, H. (2013), "Adaptation strategies for maize cultivation under climate change in Iran: irrigation and planting date management", Mitigation and Adaptation Strategies for Global Change, Vol. 18 No. 2, pp. 265-617.

Muthanna (2013), "Perception of climate change among farm women and its impact on production of redgram”, M.Sc. (Agri.) Thesis, University of Agriculture and Science, Bengaluru.

Prasad, P.V., Craufurd, P.A., Summerfield, R.J. and Wheeler, T.R. (2000), "Effects of short episodes of heat stress on flower production and fruit-set of groundnut (Arachis hypogaea L.)", Journal of Experimental Botany, Vol. 51 No. 345, pp. 777-784.

Poudel, S. and Kotani, K. (2013), "Climatic impacts on crop yield and its variability in Nepal: do they vary across seasons and altitudes?", Climatic Change, Vol. 116 No. 2, pp. 327-355.

Rao, B.B., Santhibhushan, P., Chowdary, V.M., Sandeep, V.U.M. and Rao, B.V. (2014), "Rising minimum temperature trends over India in recent decades: implications for agricultural production", Global and Planetary Change, Vol. 117, pp. 1-8.

Ray, D.K., Mueller, N.D., West, P.C. and Foley, J.A. (2013), "Yield trends are insufficient to double global crop production by 2050", PLoS One, Vol. 8 No. 6, p. 66428, doi: 10.1371/journal.pone. 0066428.

Ray, G.L. and Mandal, S. (2006), Research Methods in Social Sciences and Extension Education, Kalyani Publishers, Ludhiana.

Schlenker, W. and Lobell, D.B. (2010), "Robust negative impacts of climate change on Africa agriculture”, Environmental Research Letters, Vol. 5 No. 1, p. 014010. 
IJCCSM 12,5

Shanabhoga, M.B., Krishnamurthy, B. and Suresha, S.V. (2019), "Assessment of vulnerability to climate change among the districts of Hyderabad Karnataka region", International Journal of Agriculture Sciences, Vol. 11 No. 16, pp. 8932-8935.

Smit, B. and Wandel, J. (2006), "Adaptation, adaptive capacity and vulnerability”, Global Environmental Change, Vol. 16 No. 3, pp. 282-292.

Soora, N.K., Aggarwal, P.K., Saxena, R., Rani, S., Jain, S. and Chauhan, N. (2013), “An assessment of regional vulnerability of rice to climate change in India", Climatic Change, Vol. 118 Nos 3/4, pp. 683-699.

Tao, F., Zhang, Z., Zhang, S., Zhu, Z. and Shi, W. (2012), "Response of crop yields to climate trends since 1980 in China”, Climate Research, Vol. 54 No. 3, pp. 233-247.

Teixeira, E.I., Fischer, G., Velthuizen, H.V., Walter, C. and Ewert, F. (2013), "Global hot spots of heat stress on agricultural crops due to climate change", Agricultural and Forest Meteorology, Vol. 170, pp. 206-215.

The Government of Karnataka (2015), A HANDBOOK of Karnataka, Karnataka Gazetteer Department, A Government of Karnataka Publication, Bengaluru, p. 817.

Tingem, M. and Rivington, M. (2009), "Adaptation for crop agriculture to climate change in Cameroon: turning on the heat", Mitigation and Adaptation Strategies for Global Change, Vol. 14 No. 2, pp. 153-168.

Vinaya Kumar, H.M. (2015), "Management of climate induced crisis by the farmers of coastal region of Karnataka state - a critical analysis. Ph.D. Thesis", Current Journal of Applied Science and Technology, Vol. 30 No. 5.

Vinaya Kumar, H.M., Shivamurthy, M. and Lunagaria, M.M. (2017a), "Rainfall trend analysis and adaptation strategies to manage climate-induced crisis in coastal zone of Karnataka, India", Journal of Scientific Research and Reports, Vol. 13 No. 5, pp. 1-11, doi: 10.9734/JSRR/2017/32709.

Vinaya Kumar, H.M. and Shivamurthy, M. (2018), "Adaptation to mitigate climate-induced crisis by farmers in coastal zone of Karnataka", Current Journal of Applied Science and Technology, Vol. 30 No. 5, pp. 1-13, doi: 10.9734/CJAST/2018/41134.

Vinaya Kumar, H.M., Shivamurthy, M. and Lunagaria, M.M. (2017b), "Impact of rainfall variability and trend on rice yield in coastal Karnataka", Journal of Scientific Research and Reports, Vol. 13 No. 5, pp. 286-287.

Vinaya Kumar, H.M., Shivamurthy, M., Govinda Gowda, V. and Biradar, G.S. (2017c), "Assessing decision-making and economic performance of farmers to manage climate-induced crisis in coastal Karnataka (India)", Climatic Change, Vol. 142 Nos 1/2, pp. 143-153, doi: 10.1007/s10584017-1928-x.

Wassmann, R., Jagadish, S.V.K., Sumfleth, K., Pathak, H., Howell, G., Ismail, A., Serraj, R., Redona, E., Singh, R.K. and Heuer, S. (2009), "Regional vulnerability of climate change impacts on Asian rice production and scope for adaptation", Advances in Agronomy, pp. 91-133.

\section{Corresponding author}

Shanabhoga M.B. can be contacted at: shanabhogamb@gmail.com

For instructions on how to order reprints of this article, please visit our website:

www.emeraldgrouppublishing.com/licensing/reprints.htm

Or contact us for further details: permissions@emeraldinsight.com 